\begin{tabular}{ccc}
\hline International Journal of Advanced Geosciences, 8(2)(2020) 214-218 \\
International Journal of Advanced Geosciences \\
WPC \\
Website: www.sciencepubco.com/index.php/IJAG \\
Research paper
\end{tabular}

\title{
Assessment of heavy metals contamination of the water resources in the vicinity of Barapukuria Coal Mine, Phulbari, Dinajpur, NW Bangladesh
}

\author{
Mohammad Nazmul Haque ${ }^{1}$, A. H. M. Selim Reza ${ }^{1}$, Sohail Kabir ${ }^{1}$, Md. Aminul \\ Ahsan $^{2}$, Sudip Saha ${ }^{1}$, Md Ahedul Akbor ${ }^{2}$ \\ ${ }^{1}$ Department of Geology and Mining, University of Rajshahi, Rajshahi-6205, Bangladesh \\ ${ }^{2}$ Analytical Research Division Laboratories, Bangladesh Council of Scientific and Industrial Research (BCSIR), Dhaka, Bangladesh \\ *Corresponding author E-mail: sudips_geologist@yahoo.com
}

\begin{abstract}
The present research work shows that the concentrations of heavy metals can be expressed as $\mathrm{Fe}>\mathrm{Mn}>\mathrm{Zn}>\mathrm{Ni}>\mathrm{Cr}>\mathrm{Pb}>\mathrm{Co}>\mathrm{As}$ in the groundwater of Phulbari area, Dinajpur, Bangladesh on the basis of their abundance. The Plio-Pleistocene Dupi Tila aquifer sediment is principally composed of quartz, feldspar and lithic grains and is characterized by low ZTR index. Seventeen groundwater samples have higher iron concentrations than the permissible limit of WHO, 2004. The chemical weathering of pyrite release iron in the natural water of the study area. The manganese content of two groundwater samples is higher than the acceptable limit. The high abundance of potassium in $11.11 \%$ water samples is indicative of the influence of agricultural activity in the investigated area. The factor analysis reveals the dominance of four factors that comprise $77.276 \%$ of the groundwater sample. The contamination index (Cd) for the heavy metals were performed and $88.89 \%$ of the groundwater samples have low contamination index. The calcium of the groundwater is resulted from the dissolution of carbonate rocks. The low arsenic concentrations indicate the fast flowing nature of the groundwater and/or low arsenic content of the aquifer sediments. The low cobalt content of the groundwater reflects the low cobalt concentration of the aquifer sediments. The heavy metal chemistry of the groundwater of the study area reveals that the quality of the water is influenced by the geogenic sources as well as the anthropogenic activities like coal mining and agricultural activities.
\end{abstract}

Keywords: Factor analysis; Contamination Index (Cd); Iron; Arsenic; Pyrite and ZTR Index.

\section{Introduction}

Groundwater is a natural resource that is necessary for the economic development of a country. Groundwater is used for industrial, domestic and agricultural activities. The study of groundwater quality is a regular routine work for the proper management of the groundwater. The groundwater may be contaminated from various activities and they can be categorized either geogenic or anthropogenic. The present research work deals with the assessment of the groundwater quality of Phulbari Upazila, Dinajpur, Bangladesh where the groundwater can be contaminated principally from the mining and agricultural activities.

The study of the stratigraphic succession of the Barapukuria Basin shows that the coal bearing Gondwana Group overlies on the Precambrian basement complex (Hossain 1999). Hossain et al 2017 summarized that the minerals like illite-smectite, kaolinite, chlorite, sericite, laumontite with quartz, opal-CT, feldspar, muscovite, pyrite and limonite comprise the coal bearing Gondwana sequence of the study area. In Barapukuria Coal Basin the average percentage of carbon is $64.59 \%$, hydrogen is $4.67 \%$, nitrogen is $3.24 \%$ and sulfur is $0.45 \%$ (Pal et al. 2018).

The Gondwana Group is underlain by the Dupi Tila Formation in the studied coal Basin (Wardell 1991). The Dupi Tila Formation constitute the main aquifer of the Barapukuria Coal Mine area. The Dupi Tile sandstone is characterized by the low ZTR index (Roy et al. 2004).The Plio-Pleistocene medium to coarse-grained Dupi Tila sandstone is mainly composed of $95.17 \% \mathrm{SiO}_{2}$ and $2.11 \% \mathrm{Al}_{2} \mathrm{O}_{3}$ on an average and the study of the mineralogical composition shows the presence of quartz, feldspar and lithic grains in the sandstone (Rahman et al. 2014).The geochemical study of the water of the Phulbari area reveals that the major cation facies are $\mathrm{Ca}^{2+}$ and $\mathrm{Na}^{+}$whereas the major anion facies are $\mathrm{HCO}_{3}{ }^{1-}$ and $\mathrm{SO}_{4}{ }^{2-}$ (Howlader et al. 2014).

Barapukuria Coal Mine is located in Phulbari, Dinajpur, Bangladesh. Its geographical coordinates are $25^{\circ} 31^{\prime} 45^{\prime \prime} \mathrm{N}$ to $25^{\circ} 33^{\prime} 05^{\prime \prime} \mathrm{N}$ latitude and $88^{\circ} 57^{\prime} 48^{\prime \prime} \mathrm{E}$ to $88^{\circ} 58^{\prime} 53^{\prime} \mathrm{E}$ longitude (Figure 1). The $\mathrm{pH}$ value of all water samples around the Barapukuria coal mine are above 7 which indicate the alkaline nature of the water and the colour of the coal leached drainage water is blackish and the colour of the irrigation water is slightly blackish (Fardushe et al. 2014). The present research work is carried out to show the heavy metal concentrations of the groundwater in order to determine their source and contamination level using contamination index of Backman et al., 1998. 


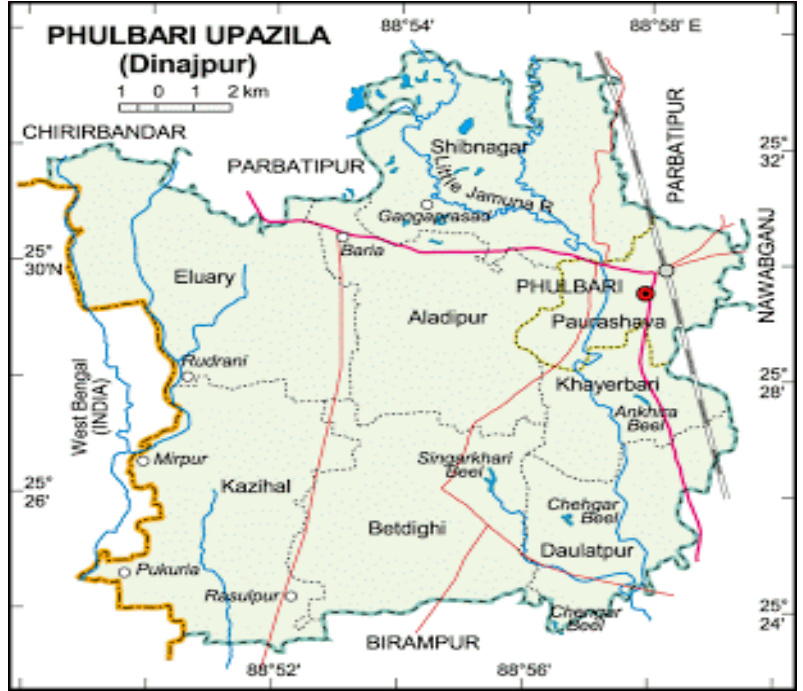

Fig. 1: Map of the Study Area.

\section{Methodology}

\section{Collection of Water Samples}

Sixteen mine drainage and nearby wetlands drainage water and two groundwater samples were collected from coal mine area of Phulbari Upazilla in March, 2014. The water samples were collected in $500 \mathrm{ml}$ plastic bottles, which were corked immediately to make them airtight. Samples were acidified during collection and stored in a refrigerator at $4{ }^{\circ} \mathrm{C}$. All necessary water sampling guidelines were followed during sampling. The physical parameters such as $\mathrm{pH}, \mathrm{EC}$, and temperature were measured in the field. The concentrations of major trace elements were measured by atomic absorption spectrometer (Shimadzu, AA 240FS) in the Analytical Research Division Laboratories, Bangladesh Council of Scientific and Industrial Research (BCSIR), Dhaka.

\section{Methods of Water Samples Analysis}

Varian spectra AA 240 FS and Graphite furnace atomic absorption spectrometry (GF AAS), Varian spectra AA 240 Z were used for water analysis. The intensity of standard solutions was measured by Atomic Absorption Spectrometer (AAS) and the respective intensity values were plotted against the $\mathrm{mg} / \mathrm{L}$ values in intensity versus $\mathrm{mg} / \mathrm{L}$ graph to obtain standard curve. Then the measurements of the intensity of the water samples were carried out.

\section{The Contamination Index $\left(\mathbf{C}_{d}\right)$ of Water Samples}

Quality of water takes interest of the researches and consumers (for drinking and irrigation), through which populations are exposed to harmful elements from industrial, anthropogenic and/or geological origin. Many techniques are used for assessment and visualization of hazardous defined elements. One of the approaches to calculate contamination of water bodies is by using contamination index, which takes into consideration both the number of parameters exceeding the upper permissible limits or guide values of the potentially harmful elements (Backman et al., 1998). Calculation of the contamination degree (Cd) was carried out separately for each analyzed sample of water, as a sum of the contamination factors of individual components exceeding the upper permissible values. Hence, the contamination index summarizes the combined effects of several quality parameters considered harmful to household water. According to (Backman et al., 1998), the calculation scheme of contamination index (Cd) is as follows:

$C_{d}=\sum_{i=1}^{n} C_{f i}$

Where,

$C_{f i}=\frac{C_{A i}}{C_{N i}}-1$

$\mathrm{C}_{\mathrm{fi}}=$ Contamination factor for the $\mathrm{i}$-th component

$\mathrm{C}_{\mathrm{Ai}}=$ Analytical value of the $\mathrm{i}$-th component

$\mathrm{C}_{\mathrm{Ni}}=$ Upper permissible concentration of the i-th component ( $\mathrm{N}$ denotes the 'normative value')

\section{Results and discussion}

\section{Geochemistry of groundwater}

Table 1: Statistical Summary of Results of Chemical Analysis of Drainage Water, BCM, Dinajpur

\begin{tabular}{|c|c|c|c|c|c|c|c|c|c|c|}
\hline Parameters & $\begin{array}{l}\mathrm{Fe} \\
\mathrm{mg} / \mathrm{L}\end{array}$ & $\begin{array}{l}\mathrm{Mn} \\
\mathrm{mg} / \mathrm{L}\end{array}$ & $\begin{array}{l}\mathrm{Zn} \\
\mathrm{mg} / \mathrm{L}\end{array}$ & $\begin{array}{l}\mathrm{Ni} \\
\mathrm{mg} / \mathrm{L}\end{array}$ & $\begin{array}{l}\mathrm{Cr} \\
\mathrm{mg} / \mathrm{L}\end{array}$ & $\begin{array}{l}\mathrm{Pb} \\
\mathrm{mg} / \mathrm{L}\end{array}$ & $\begin{array}{l}\mathrm{As} \\
\mathrm{mg} / \mathrm{L}\end{array}$ & $\begin{array}{l}\text { Co } \\
\mathrm{mg} / \mathrm{L}\end{array}$ & $\begin{array}{l}\mathrm{Ca} \\
\mathrm{mg} / \mathrm{L}\end{array}$ & $\begin{array}{l}\mathrm{K} \\
\mathrm{mg} / \mathrm{L}\end{array}$ \\
\hline Mean & 1.987 & 0.303 & 0.072 & 0.068 & 0.019 & 0.004 & 0.000 & 0.002 & 37.712 & 9.405 \\
\hline Median & 1.794 & 0.161 & 0.054 & 0.067 & 0.019 & 0.002 & 0.000 & 0.000 & 37.139 & 9.513 \\
\hline SD & 0.651 & 0.370 & 0.044 & 0.012 & 0.003 & 0.005 & 0.001 & 0.003 & 7.762 & 3.118 \\
\hline Variance & 0.424 & 0.137 & 0.002 & 0.000 & 0.000 & 0.000 & 0.000 & 0.000 & 60.253 & 9.725 \\
\hline Skewness & -0.047 & 3.701 & 1.222 & 0.232 & 1.024 & 2.891 & 3.013 & 1.584 & 1.031 & -0.909 \\
\hline
\end{tabular}




\begin{tabular}{|c|c|c|c|c|c|c|c|c|c|c|}
\hline Kurtosis & -0.306 & 14.664 & 1.359 & 0.795 & 1.519 & 8.115 & 8.727 & 0.930 & 4.914 & 1.543 \\
\hline Max & 3.079 & 1.766 & 0.190 & 0.095 & 0.027 & 0.020 & 0.005 & 0.008 & 61.470 & 14.450 \\
\hline Min & 0.576 & 0.088 & 0.018 & 0.044 & 0.015 & 0.001 & 0.000 & 0.000 & 20.715 & 2.023 \\
\hline Range & 2.503 & 1.678 & 0.172 & 0.051 & 0.012 & 0.019 & 0.005 & 0.008 & 40.755 & 12.427 \\
\hline
\end{tabular}

Table 1 shows the chemical composition of the groundwater of Phulbari area, Dinajpur, Bangladesh. The concentration of calcium is highest on the basis of the mean content of the metals. The maximum concentration of calcium is $61.470 \mathrm{mg} / \mathrm{L} \mathrm{in} \mathrm{Phulbari} \mathrm{area.} \mathrm{The}$ calcium derived from the dissolution of carbonate rocks (Howlader et al. 2014: Moni et al. 2019). Potassium is the second abundant metal in the investigated groundwater samples which mean value is $9.405 \mathrm{mg} / \mathrm{L}$. The enrichment of potassium in groundwater is resulted from the use of urea fertilizers (Divya and Belagali, 2012: Saha et al., 2019). The chemical weathering of sylvite and silicates especially clay minerals are the principal source of potassium in the groundwater samples of the investigated area (Sultana 2009). Table 2 shows that two of the groundwater samples exceed the permissible limit of potassium of WHO 2004.

Table 2: Correlation Between the Groundwater Samples of BCM

\begin{tabular}{|c|c|c|c|c|c|c|c|c|c|}
\hline \multirow[t]{2}{*}{$\begin{array}{l}\text { Param- } \\
\text { eters }\end{array}$} & \multirow[t]{2}{*}{ Unit } & \multirow[t]{2}{*}{$\begin{array}{l}\text { WHO drinking water stand- } \\
\text { ard WHO (2004) }\end{array}$} & \multirow[t]{2}{*}{$\begin{array}{l}\text { BD Guideline } \\
(2009)\end{array}$} & \multicolumn{5}{|c|}{ Groundwater in the study area } & \multirow[t]{2}{*}{$\begin{array}{l}\text { Number of samples above } \\
\text { acceptable limit }\end{array}$} \\
\hline & & & & Min. & Max & $\begin{array}{l}\text { Aver- } \\
\text { age }\end{array}$ & $\begin{array}{l}\text { Me- } \\
\text { dian }\end{array}$ & Stdev & \\
\hline $\mathrm{Fe}$ & $\mathrm{mg} / \mathrm{L}$ & $0.3-1.0$ & 1.0 & 0.576 & 3.079 & 1.987 & 1.794 & 0.651 & 17 Samples \\
\hline Mn & $\mathrm{mg} / \mathrm{L}$ & 0.4 & 1.0 & 0.088 & 1.766 & 0.303 & 0.161 & 0.370 & 2 Samples \\
\hline $\mathrm{Zn}$ & $\mathrm{mg} / \mathrm{L}$ & 3.0 & 5.0 & 0.018 & 0.190 & 0.072 & 0.054 & 0.044 & None \\
\hline $\mathrm{Ni}$ & $\mathrm{mg} / \mathrm{L}$ & 0.02 & 0.1 & 0.044 & 0.095 & 0.068 & 0.067 & 0.012 & None \\
\hline $\mathrm{Cr}$ & $\mathrm{mg} / \mathrm{L}$ & 0.05 & 0.05 & 0.015 & 0.027 & 0.019 & 0.019 & 0.003 & None \\
\hline $\mathrm{Pb}$ & $\mathrm{mg} / \mathrm{L}$ & 0.01 & 0.05 & 0.001 & 0.020 & 0.004 & 0.002 & 0.005 & 2 Samples \\
\hline As & $\mathrm{mg} / \mathrm{L}$ & 0.01 & 0.05 & 0.000 & 0.005 & 0.0009 & 0.000 & 0.001 & None \\
\hline $\mathrm{Co}$ & $\mathrm{mg} / \mathrm{L}$ & 0.05 & - & 0.000 & 0.008 & 0.002 & 0.000 & 0.003 & None \\
\hline $\mathrm{Ca}$ & $\mathrm{mg} / \mathrm{L}$ & $75-200$ & - & 20.715 & 61.470 & 37.712 & 37.139 & 7.762 & None \\
\hline $\mathrm{K}$ & $\mathrm{mg} / \mathrm{L}$ & 12 & 12 & 2.023 & 14.450 & 9.405 & 9.513 & 3.118 & 2 Samples \\
\hline
\end{tabular}

The mean abundance of the heavy metals of the groundwater samples can be expressed as $\mathrm{Fe}>\mathrm{Mn}>\mathrm{Zn}>\mathrm{Ni}>\mathrm{Cr}>\mathrm{Pb}>\mathrm{Co}>\mathrm{As}(\mathrm{Figure} 2)$. Among the heavy metals the mean concentration of iron is highest and the numerical value is $1.987 \mathrm{mg} / \mathrm{L}$. Seventeen of the groundwater samples exceed the maximum permissible limit of iron (WHO 2004). The maximum concentrations of Mn is $1.766 \mathrm{mg} / \mathrm{L}$ and two of the samples have higher content of the permissible limit of WHO 2004. The mean concentrations of arsenic of the groundwater samples are $0.00099 \mathrm{mg} / \mathrm{L}$. The arsenic concentrations of the main aquifer Dupi Tila Formation varies from 2.9 to $6.6 \mathrm{ppm}$ (Rahman et al. 2014), which is lower than the aquifer sediments of the arsenic prone groundwater areas of Bangladesh. All of the groundwater samples have the As concentrations below the permissible limit of WHO 2004.



Fig. 2: The Mean Concentration of Heavy Metals in the Groundwater of Phulbari Area

The mean cobalt content of the groundwater samples of the study area is $0.002 \mathrm{mg} / \mathrm{L}$ and none of the samples exceeds the maximum permissible limit of WHO 2004. The cobalt concentration of the aquifer sediments ranges from the below detection limit to $6 \mathrm{ppm}$ in the sediments of Surma Basin (Rahman et al. 2014). This may result the lower concentration of cobalt in the groundwater of Phulbari.

Table 3: Pearson Correlation Coefficient Matrix of Drainage Water of BCM

\begin{tabular}{lllllllllll}
\hline & $\mathrm{Fe}$ & $\mathrm{Mn}$ & $\mathrm{Zn}$ & $\mathrm{Ni}$ & $\mathrm{Cr}$ & $\mathrm{Pb}$ & $\mathrm{As}$ & $\mathrm{Co}$ & $\mathrm{Ca}$ & $\mathrm{K}$ \\
\hline $\mathrm{Fe}$ & 1.000 & & & & & & & & & \\
$\mathrm{Mn}$ & 0.359 & 1.000 & & & & & & & \\
$\mathrm{Zn}$ & 0.288 & 0.023 & 1.000 & & & & & & \\
$\mathrm{Ni}$ & $0.682^{* *}$ & $0.524^{*}$ & 0.242 & 1.000 & & & & & \\
$\mathrm{Cr}$ & 0.256 & -0.058 & -0.022 & 0.125 & 1.000 & & & & \\
$\mathrm{~Pb}$ & -0.093 & 0.000 & -0.176 & -0.133 & 0.385 & 1.000 & & & \\
$\mathrm{As}$ & 0.158 & -0.087 & 0.333 & 0.037 & -0.361 & -0.076 & 1.000 & & \\
$\mathrm{Co}$ & -0.046 & 0.121 & 0.058 & 0.292 & $-0.531^{*}$ & -0.252 & 0.408 & 1.000 & 1.000 \\
$\mathrm{Ca}$ & $0.538^{*}$ & $0.666^{* *}$ & 0.295 & $0.644^{* *}$ & -0.005 & -0.372 & 0.015 & 0.184 & \\
$\mathrm{~K}$ & 0.247 & -0.026 & 0.291 & 0.417 & 0.156 & -0.292 & 0.051 & -0.024 & $0.620^{* *}$ & 1.000 \\
\hline
\end{tabular}

**. Correlation is significant at the 0.01 level (2-tailed).

*. Correlation is significant at the 0.05 level (2-tailed).

The iron is derived from the chemical weathering of iron bearing minerals like pyrite, arsenopyrite. The arsenic shows insignificant positive correlations with iron (Figure 3) and which reveals that the arsenic is released in the groundwater by the oxidation of iron sulfide minerals (Reza et al. 2010c). The insignificant negative correlations between As and Mn is indicative of their derivation from the different sources. 


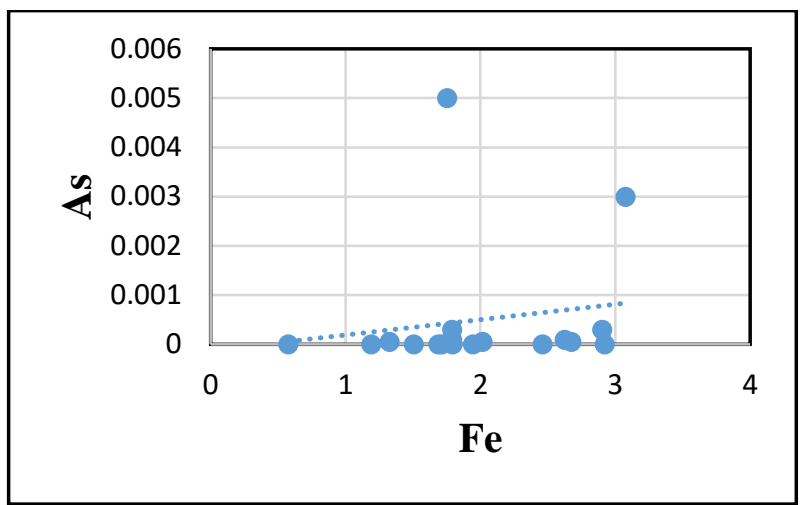

Fig 3: The Positive Correlation of Fe and As.

\section{Factor analysis}

From the factor analysis it can be concluded that first four factors comprise the ratios of $32.32 \%, 20.44 \%, 13.20 \%$ and $11.32 \%$ respectively and total $77.276 \%$. The first factor (Factor -1) is characterized by the dominance of $\mathrm{Ca}, \mathrm{Fe}$ and Ni, that principally indicates the dissolution of $\mathrm{Fe}$ and $\mathrm{Ca}$ bearing minerals like pyrite and carbonates. The second factor (Factor-2) is the indicator of $\mathrm{Cr}$ contamination within the study area. The third factor (Factor-3) is characterized by the dominance of $\mathrm{K}$ and $\mathrm{Zn}$ which reveals the influx of metal from the agricultural activities within the groundwater. Factor-4 is influenced by the fluctuations of $\mathrm{Pb}$ and As metals in the groundwater samples of the investigated area.

Table 4: Total Variance Explained

\begin{tabular}{llllll}
\hline \multirow{2}{*}{ Component } & \multicolumn{2}{c}{$\begin{array}{l}\text { Initial Eigenvalues } \\
\text { Total }\end{array}$} & \% of Variance & Cumulative \% & \multicolumn{2}{c}{$\begin{array}{c}\text { Extraction Sums of Squared Loadings } \\
\text { Total }\end{array}$} & of Variance \\
\hline 1 & 3.232 & 32.321 & 32.321 & 3.232 & 32.321 \\
2 & 2.044 & 20.439 & 52.761 & 2.044 & 20.439 \\
3 & 1.320 & 13.200 & 65.961 & 1.320 & 13.200 \\
4 & 1.131 & 11.315 & 77.276 & 1.131 & 11.315 \\
5 & .698 & 6.983 & 84.259 & & \\
6 & .597 & 5.974 & 90.233 & & \\
7 & .493 & 4.931 & 95.164 & & \\
8 & .287 & 2.867 & 98.031 & & \\
9 & .175 & 1.746 & 99.777 & & \\
10 & .022 & .223 & 100.000 & & \\
\hline
\end{tabular}

Extraction Method: Principal Component Analysis.

Table 5: Varimax Rotated Factors for First Four Components

\begin{tabular}{lllll}
\hline & Component & & & \\
& Factor -1 & Factor -2 & Factor -3 & Factor -4 \\
\hline $\mathrm{Fe}$ & .717 & .301 & .034 & .343 \\
$\mathrm{Mn}$ & .591 & .151 & -.671 & .055 \\
$\mathrm{Zn}$ & .455 & -.147 & .562 & .301 \\
$\mathrm{Ni}$ & .843 & .162 & -.175 & .134 \\
$\mathrm{Cr}$ & -.020 & .859 & .224 & .143 \\
$\mathrm{~Pb}$ & -.388 & .450 & -.187 & .607 \\
$\mathrm{As}$ & .199 & -.617 & .278 & .561 \\
$\mathrm{Co}$ & .293 & -.733 & -.280 & .097 \\
$\mathrm{Ca}$ & .907 & .085 & -.096 & -.236 \\
$\mathrm{~K}$ & .592 & .131 & .522 & -.366 \\
\hline $\mathrm{Ex}$ & .986 & \\
\hline
\end{tabular}

Extraction Method: Principal Component Analysis.

a. 4 components extracted.

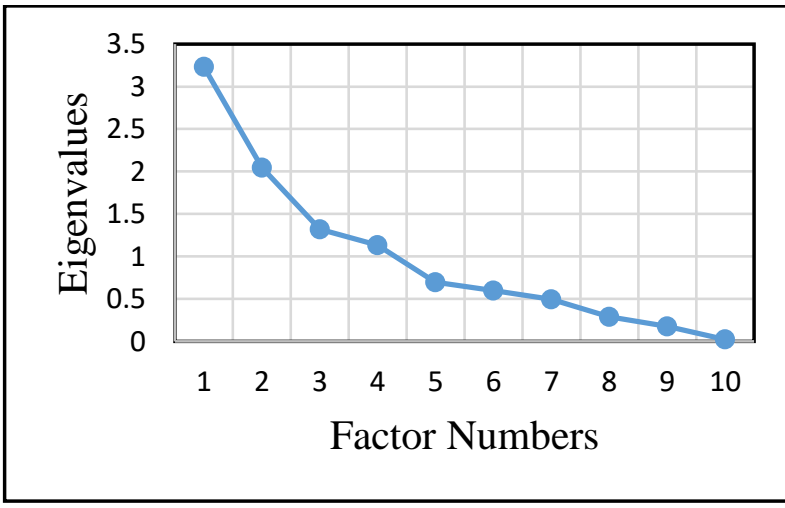

Fig. 4: Scree Plot of Eigenvalues 


\section{The Contamination Index $(\mathrm{Cd})$ of Groundwater}

Table 6 shows the contamination index of the studied groundwater samples. $88.89 \%$ of the groundwater samples show low level of contamination, $5.56 \%$ medium level of contamination and 5.56\% indicative of high contamination. From table 2 it can be summarized that most of the groundwater samples are contaminated by iron and minor amounts of the groundwater samples are contaminated by the excessive amounts of $\mathrm{Mn}$ and $\mathrm{K}$.

Table 6: Classification of Contamination Index (Backman et al. 1998)

\begin{tabular}{lll}
\hline $\mathrm{C}_{\mathrm{d}}$ & Class & Conclusion \\
\hline $\mathrm{C}_{\mathrm{d}}<1$ & Low Contamination & $88.89 \%$ samples \\
$\mathrm{C}_{\mathrm{d}} 1-3$ & Medium Contamination & $5.56 \%$ samples \\
$\mathrm{C}_{\mathrm{d}}>3$ & High Contamination & $5.56 \%$ samples \\
$\mathrm{C}_{\mathrm{d}}=$ Contamination Index & \\
\hline
\end{tabular}

\section{Conclusion}

The Plio-Pleistocene Dupi Tila sandstone aquifer is composed of quartz, feldspar and lithic grains. The average amount of $\mathrm{SiO}_{2}$ is $95.17 \%$ whereas the arsenic content varies from 2.9 to $6.6 \mathrm{ppm}$. The present research work shows that the coal mining activities have less influence on the contamination of groundwater composition of the mining area Phulbari as $88.89 \%$ of the groundwater have low contamination index (Cd). The concentration of iron is higher than the desired amount which shows the dissolution of iron bearing minerals like pyrite. The higher amount of potassium might have resulted from the agricultural activities of the investigated area. The insignificant positive correlation between $\mathrm{Fe}$ and As reveals that the influx of arsenic from the oxidation of iron sulfide minerals. The low concentration of arsenic in the groundwater indicates that the aquifer sediments have low arsenic content and/or fast flowing nature of the groundwater. The low cobalt content of the groundwater reflects the low cobalt concentration of the aquifer sediments. The factor analysis reveals that four principal factors constitute $77.276 \%$ of the groundwater samples and the dominance of calcium is indicative of dissolution of carbonate rocks. The further research works can be taken focusing on the physical characteristics of groundwater and mine drainage water like $\mathrm{pH}$, TDS, TSS and their impact on the contamination of the soil resources of the study area.

\section{Acknowledgement}

The authors are thankful to the Analytical Research Division Laboratories, Bangladesh Council of Scientific and Industrial Research (BCSIR), Dhaka for providing kind permission to analyze the water samples in the Laboratory of BCSIR, Dhaka. The authors convey due thanks to the Chairman, Department of Geology and Mining, University of Rajshahi, Bangladesh for arranging the research work.

Funding: No funding.

Conflict of interest: No conflict of interest.

\section{References}

[1] Backman B, Bodis ` D, Lahermo P, Rapant S, Tarvainen T (1998) Application of a groundwater contamination index inFinland and Slovakia. Environmental Geology 36 (1-2): 55-64. https://doi.org/10.1007/s002540050320.

[2] Divya J, Belagali SL (2012) Impact of chemical fertilizers on water quality in selected agricultural areas of Mysore district, Karnataka, India. International Journal of Environmental Sciences 2(3): 1449-1458. https://doi.org/10.6088/ijes.00202030030.

[3] Fardushe RS., Hoque MM, Roy S (2014) Assessment of Soil and Water Quality of Barapukuria Coal Mining Site, Dinajpur, Bangladesh. Bangladesh J. Sci. Res. 27(1): 63-73. https://doi.org/10.3329/bjsr.v27i1.26225.

[4] Hossain I (1999) Lithofacies and petrographic study of the Gondwana Group in the boreholes GDH-40 and GDH-43, Barapukuria Basin, Dinajpur, Bangladesh. An unpublished M.Sc thesis, Dept. of Geology and Mining, University of Rajshahi.

[5] Hossain I, Tsunogae T, Islam MS, Roy RR, Talukder S (2017) Mineralogy of Gondwana Sequence in Barapukuria Formation, Bangladesh. Earth Evolution Sciences, 11: 3-22.

[6] Howlader MF, Deb, PK, Mazumder ATMSH, Ahmed M (2014) Evaluation of water resources around Barapukuria coal mine industrial area, Dinajpur, Bangladesh. Appl. Water Sci. 4: 203-222, https://doi.org/10.1007/s13201-014-0207-5.

[7] Moni SA, Sattar GS, Reza AHMS and Ahsan MA (2019) Hydrogeochemistry and Arsenic Contamination of Shallow Aquifers in Bidyananda and Nazimkhan Unions, Rajarhat Upazila, Kurigram, Bangladesh: Journal of Geological Society of India 94: 395-404. https://doi.org/10.1007/s12594019-1327-1.

[8] Pal SK, Nipa FY, Halim MA (2018) Geochemical Analysis and Origin of Organic Matter in Coal of Barapukuria Coal Mine Bangladesh. International Journal of Scientific \& Engineering Research 9(4): 1688-1695.

[9] Rahman JJ, Sayem ASMS, Bhuiyan MH (2014) Geochemistry of the Plio-Pleistocene Dupi Tila sandstones from the Surma Basin, Bangladesh: Implications for provenance, tectonic setting and weathering. Himalayan Geology 35(2): 162-170.

[10] Reza AHMS, Jean J-S., Lee M-K, Yang H-J, Liu C-C (2010c) Arsenic enrichment and mobilization in the Holocene alluvial aquifers of the ChapaiNawabganj district, Bangladesh: a geochemical and statistical study. Appl. Geochem.25: 1280-1289. https://doi.org/10.1016/j.apgeochem.2010.06.006

[11] Roy MK, Karmakar BC, Saha S, Chaudhuri S (2004) Facies and Depositional Environment of the Dupitila Formation, Dupitila Hill Range, Jaintiapur, Sylhet, Bangladesh. Journal of Geological Society of India 63: 139-157.

[12] Saha S., Reza AHMS, Roy MK (2019) Hydrochemical evaluation of the groundwater quality of the Tista floodplain, Rangpur, Bangladesh. Applied Water Science 9,198. https://doi.org/10.1007/s13201-019-1085-7.

[13] Wardell A (1991) Techno-economic feasibility study, Barapukuria coal project, Dinajpur district, Bangladesh. vol 1, 2.

[14] WHO (2004) Guideline for Drinking Water Quality World Health Organization, Geneva., ISBN: 924 154638 7., Vol. 1: 3rd ed. 515 pp.? 